\title{
FACTORS THAT INFLUENCE RETIREMENT SELF-ACTUALISATION
}

\section{Pam P Kerr}

M Ed student, UNISA

\author{
Salomé Schulze \\ D Ed \\ Professor, Department of Further Teacher Education, UNISA \\ Corresponding author: schuls@unisa.ac.za
}

Keywords: Self-actualisation; retirement; focus groups; adjustment

\begin{abstract}
This article reports on an investigation of factors that influence self-actualisation during retirement. The aim of the research was to make recommendations on how to enhance the self-actualisation of retired people. The research explored the retirement experiences of a purposefully selected group of white retirees living in the George area in South Africa. Focus groups were conducted with 12 males and 12 females. Four groups were formed according to whether retirees were married or widowed and lived in retirement villages or independently. Findings indicate that retirement is a life stage full of challenges and that adjustment to these is a pre-requisite for self-actualisation. Adjustment and self-actualisation are enhanced by certain types of behaviour, as well as personal and social resources. Programmes can be designed to support retirees. The programme content should include the retirement phenomenon, key life areas in retirement, personal resources, adjustment-oriented responses to retirement, circumstantial factors which facilitate adjustment, self-actualising modes of behaviour and ways of overcoming problems.
\end{abstract}

\section{OPSOMMING}

In hierdie artikel word verslag gedoen oor 'n ondersoek na faktore wat self-aktualisering gedurende aftrede beïnvloed. Die doel van die navorsing was om aanbevelings te makk oor hoe om die self-aktualisering van afgetredenes te verhoog. In dié navorsing is die aftree-ervaring van 'n groep doelbewus-geselekteerde blanke afgetredenes in die George-area van Suid-Afrika ondersoek. Fokusgroeponderhoude is met 12 mans en 12 vroue gevoer. Vier groepe is gevorm, na gelang die afgetredenes getroud of wewenaars/weduwees was en of hulle in aftree-oorde gebly het of onafhanklik gewoon het. Die bevindinge toon aan dat aftrede ' $n$ lewenstadium vol uitdagings is. Aanpassing hierby is ' $n$ vereiste vir self-aktualisering. Aanpassing en self-aktualisering word verhoog deur sekere tipes gedrag, asook deur persoonlike en sosiale hulpbronne. Programme kan ontwerp word om afgetredenes te ondersteun. Die programinhoud behoort die volgende in te sluit: die verskynsel van aftrede, die sleutellewensareas gedurende aftrede, persoonlike hulpbronne, aanpassingswyses by aftrede, omstandigheidsfaktore wat aanpassing vergemaklik, selfaktualiserende gedrag en metodes om probleme te oorkom. 


\section{INTRODUCTION AND BACKGROUND}

Retirement is an important life event. In defining this event, economists seem to include two main features, namely that retirement involves the cessation of fulltime employment and that income is obtained, at least in part, from retirement pensions or annuities. Social definitions are broader, viewing retirement as role changes in work, marriage relationships, peer relationships and leisure activities (Smith, 1997:207).

As increasing numbers of people retire in their 60's or earlier and life expectancy continues to grow, the retirement period is increasing. Although the AIDS epidemic is projected to reduce life expectancy in affected countries, the older population (60 years and above) of Africa will continue to grow. For example, in South Africa, the older population is expected to double, from 3.1 million in 2000 to 5.9 million by 2030 , representing an increase in the percentage of older persons in the total population from 7 to $11.5 \%$ (Nhongo, $2000: 1)$. For the year 2050 the projected percentages (of the population) for South Africa for the age group 60 plus is $12.1 \%$ and for 80 plus, $2.2 \%$ (Kowal, Wolfson \& Dowd, 2000:18). Dychtwald (1999:98) notes that where retirement was at first expected to last three to five years, it now lasts about 20 years and is still increasing.

In spite of the fact that there is a "dearth of literature on ageing in South Africa", "... more research is needed to help individuals, families, communities, practitioners, service providers and policy makers understand the process of aging" (Mokone, 1999:134, 136). Understanding the retirement process is essential. It can be one of life's most stressful events, since it involves major changes in work, daily behaviour, social relationships and living arrangements at once (Holmes \& Rahne in Frigenti, 2000:15). However, if retirees can be supported so that they can be self-actualising individuals, a waste of human potential can be prevented.

For Maslow (1970:150), self-actualisation is characterised by "an absence of neurosis, psychopathic personality, psychosis or strong tendencies in these directions". He adds that positive evidence of self-actualisation "may loosely be described as the full use and exploitation of talents, capacities, potentialities, etc." People who are self-actualising seem to be fulfilling themselves and to be doing the best they are capable of doing. The need for self-actualisation may be compared to Erikson's ego-integrity. The main crisis of the retirement age is that of integrity versus despair (Erikson, Erikson \& Kivnivk, 1986:54). This involves balancing the tension between a sense of one's life as meaningful (integrity) and an opposing sense of one's life as having been wasted and feelings of despair. Thus, older people may move in one of two directions: decline or growth. This influences self-actualisation.

When a Boolean search was done for self-actualisation and retirement in South Africa, no hits were made (except for the study of Kerr, 2002), although some publications focussed on aspects related to self-actualisation. This article therefore reports on an investigation of the factors that may influence the self-actualisation of a selected group of South African retirees. The ultimate goal is to prevent a waste of human capability.

\section{THE RETIREMENT PROCESS}

There are a number of different (and sometimes contradictory) theories that have been proposed to explain retirement. Among others, the activity theory of Maddox (Aiken, 1995:278; Knott, 1998:38) proposed that people need to maintain productivity and social interaction to adjust well to retirement. In contrast, the disengagement theory outlined by Cumming and Henry (Aiken, 1995:277) regards retirement as a time of mutual withdrawal of the retiree from society and of society from the retiree, as his or her role is relinquished to younger people. Sagner (1999:1) confirms that "the emergence of state retirement policies did reinforce time-honoured associations of old age with disengagement, decline and obsolescence as older persons ... lost income and function". According to role theory, people have varied roles. The loss of the work role often implies that retirees are roleless. On the other hand, the continuity theory proposed by Atchley (Quick \& Moen, 1998:45) emphasises that retirees tend to maintain previous life-style patterns, values and habits. Thus activities chosen before retirement have a profound effect on life after retirement. All these theories see retirement as a process. Atchley (1988:196-198) identified eight phases in the retirement process: (1) preretirement; (2) the honeymoon phase in which retirees may feel free to do new things, lasting from a few weeks to several years; (3) the retirement routine phase, when routines are developed; (4) the rest and relaxation phase, 
when many go through a temporary period of lowered activity levels; (5) disenchantment, when the retirement is disrupted by some difficulty, for example, the death of a spouse; (6) reorientation; (7) routine; and (8) termination. Numerous life changes occur during the abovementioned phases.

\section{MAJOR LIFE CHANGES ASSOCIATED WITH RETIREMENT}

The following are changes associated with retirement, which may influence self-actualisation. For many retirees, a loss of the work role implies change in income, authority, status, respect, social interaction and unstructured time (Le Roux, 1999:128). How to use this time meaningfully is a major issue confronting retirees. While some see retirement as an opportunity to explore new avenues, others may experience a lack of purpose. This can be damaging to the self-esteem. However, if the work role was experienced negatively, retirement may be a welcome escape (Quick \& Moen, 1998:45).

Often, life-long friends are given up and feelings of social isolation are experienced. Retirees have to build new relations, since the social support of fellow retirees is important for self-actualisation (Carter \& Cook, 1995:69). Participation in clubs and churches may therefore become important. Often, family members have to adapt to more time spent together. This can escalate family conflict and change marital relationships. Wilkerson and Hichens (1989) highlight potential sources of conflict, including changes in sleeping habits and power sharing in the home. A wife may feel that her husband is underfoot and find it difficult to continue with previous activities. However, some couples may experience an increase in marital satisfaction (Kulik, 1999:286-293).

Retirement means a reduction in income for most retirees (Harris, 1990:275). This may influence the quality of retirement. Many retirees have to adjust to smaller homes, or retirement homes.

The challenges also include physical changes (for example, sensory and health changes); cognitive changes (including loss of memory); and losses caused by the death of friends or a spouse, bringing the individual face to face with "the meaning of life" (Atchley, 1988:110; Le
Roux, 1999:129).

\section{FACTORS INFLUENCING RETIREMENT ADJUSTMENT AND SELF-ACTUALI- SATION}

Baltes and Baltes (1990:53) believe that to cope, retirees need to respond with resilience to the abovementioned challenges. Numerous factors influence adjustment, including the timing of and the reasons for retirement. The more the planning and preparation for retirement, the more likely that a smooth retirement transition may be experienced (Knott, 1998:124-130).

Adaptation is also easier for those with the necessary personal resources (such as sufficient income, effective coping skills, qualities such as flexibility and a positive attitude towards retirement, and good physical and psychological health), for those who are successfully able to expand or create new work and social roles (using time effectively), and for those who have a good social support system. Research has shown that married retirees generally adjust better than those who are single (Mein, Higgs, Ferrie \& Stansfiedl, 1998:543; Fouquereau, Fernandes \& Mullet, 1999:55-56; Hong \& Duff, 1997:275-281).

When gender is considered, a study by Quick and Moen (1998:44-63) indicates that women who had stressful jobs, rate retirement as better than the pre-retirement years. Men are more inclined to regard work as being the most satisfying part of their lives. Carter and Cook (1995:71-74) showed that if workers' identities were dependent on their profession, retirement adjustment may be difficult. Certain personality types also adjust easier, for example, mature men, rocking-chair men (who welcome the relaxation of retirement), or so-called armoured men (who build active lifestyles).

There may be some debate around the self-actualisation of retirees. Maslow (1972) included six important characteristics of self-actualisers: healthy attitudes to the self, growth, integration, autonomy, an accurate perception of reality and environmental mastery. Healthy attitudes towards the self include listening to impulse voices (Maslow, 1972:46), which means shutting out the voices and advice of others and listening to one's own internal arbiter. This aspect may be increasingly difficult as retirees grow older and become more de- 
pendent.

Regarding the need to make growth choices instead of fear choices and lead productive lives, there is a belief that during retirement people disengage and relinquish their roles to younger people (Cumming \& Henry in Aiken, 1995:277). Negative stereotypes of aging as a time of decline may further undermine the idea of continued growth during this life stage, resulting in people not being open to new experiences or not taking up new challenges, and thus not self-actualising.

In addition to the above, authors differ on the issue of autonomy (freedom of choice). Individuals with a high internal locus of control are expected to adjust better to retirement. However, Fouquereau et al. (1999:56) have found that these individuals will try to manage their own affairs and remain autonomous and thus not be satisfied with retirement. Those with a low internal locus of control will more readily look to help from others when necessary. Thus, self-actualisation during retirement needs further investigation.

\section{THE SOUTH AFRICAN CONTEXT}

As mentioned, South African studies have not investigated self-actualisation per se, but rather one or more aspects related to self-actualisation. Most of these studies were context specific, since the contexts of different cultural groups may be vastly dissimilar. For example, health and health care issues are important aspects of the self-actualisation of older people, but the contexts of different cultural groups are paradoxical. Although the country has a well-established first-world health care system, the health care of the majority of the population "has as a result of apartheid policies been seriously compromised" (Charlton, 1998:1).

Using black families in her sample, Mokone's (1999:133-137) study investigated the role these families play as support systems for the elderly. Although it has always been assumed that black families are able and willing to take care of their elderly, supportive family resources are hardly available where the urban black aged are concerned. Seventy-two percent of the black families regarded a home for the aged as the most suitable form of accommodation. A study conducted in a black community of the Northern Province revealed that an individual retiree's behaviour is largely deter- mined by complex societal structures, such as social networks (Phaswana, 1998:20). Often, significant contributions of older people are largely ignored, even though the ability to contribute can enhance their ability to obtain social support and social inclusion, and hence their self-actualisation (Heslop, Agyarko, AdjeteySorsey \& Mapetla, 2000:6).

Many retirees have financial difficulties that influence their self-actualisation. One South African study used 107 coloured women who were 60 years and older and living in Stellenbosch. The study reported on their clothing needs and related difficulties (Visser, Van Wyk, Senekal \& Uys, 1993:17-22).

Working with white South Africans as participants, one study (Gillespie \& Louw, 1993:25) that was significant for this research project investigated to what extent activity, especially social activity, contributed to increased life satisfaction in the elderly. A pilot study was conducted among 43 participants between the ages of 62 and 89 years. The pilot study failed to provide support for the activity theory, although the authors attributed this to the small sample size (Gillespie \& Louw, 1993:25). The debate whether "virtuous people should be able to 'sit back' when they have reached a certain age" was referred to once again in an editorial on the black culture (Sagner, 1999:2). For the majority of Africans there is no clearly defined "on"/"off" time - neither for work, nor for domestic or public roles.

All of this confirmed that an in-depth investigation into factors related to the self-actualisation of retirees needed to be context specific. The decision to focus on the retirement self-actualisation of white South Africans in the George area was influenced by the group's accessibility for the researchers (the participants being English or Afrikaans speaking), by convenience (one of the researchers lived in the George area), and by the fact that observation has indicated that many (often welleducated) people retire in that area and that there would therefore be a wealth of human potential on offer. The specific objectives of the study were (a) to investigate the factors that influence the retirement self-actualisation of this group of white retirees and the applicability of different theories on this group, and (b) to make recommendations for a programme that could be used to enhance the self-actualisation of retired people. This was done within the following research design. 


\section{RESEARCH DESIGN}

The approach was qualitative and phenomenological.

\section{Ethical measures}

The following ethical measures were taken:

Informed consent was obtained from all participants by explaining the goals of the investigation, the possible advantages and disadvantages of participating, and the credibility of the researcher who would conduct the focus groups. Consent was also obtained for recording the focus groups on audiotape. The participants were assured of confidentiality in that the researchers requested that all participants refrained from discussing what was said during the group sessions with anybody else. They were requested to sign written documents to this effect. In addition, the retirees were assured of anonymity, since they would not be identified in the research report. Participants with whom the researchers were acquainted were excluded from the research. Finally, the whole research process was planned thoroughly with a skilled and experienced researcher before the investigation started, to make sure that it was done professionally and competently.

\section{Trustworthiness}

Guba's model for trustworthiness suggests ways of reducing bias in the results (Poggenpoel, 1998:349351). Within this model, the following strategies were used: triangulation of methods (for example, observation and focus groups), asking other retirees if they could recognise the experience of retirement as described by participants, making sampling decisions carefully, using a tape recorder, having verbatim transcriptions made of interviews, obtaining feedback from participants when unsure about the meaning of their statements and having the raw data of each researcher checked by the other researcher.

\section{Sampling and data collection}

A combination of purposive sampling and snowball sampling was used. In order to narrow down the study and make a more in-depth study possible, it was decided that the sample would be chosen from white people who had been retired for at least five years and were living in the George area of South Africa. The five-year retirement minimum was recommended by Szinovaz (in Price, 2000:86) so that the influence of a "honeymoon" period or initial retirement adjustment problems could be avoided. It was also decided to include different variety marital states and living arrangements in the sample, as will be indicated.

Focus groups and field notes were used to collect data. The focus groups were homogenous with regard to marital status and living arrangements. Thus, four groups were chosen: (1) married and living independently (four males and three females, between 62 and 79 years old); (2) single/widowed and living independently (two males and four females, between 65 and 89 years old); (3) married and living in a retirement village or home (four males and one female, 69 to 75 years of age); and (4) single/widowed and living in a retirement village or home (two males and four females, 75 to 82 years old). The groups were limited to about five participants each, since smaller groups are generally advisable for older people, rather than the customary six to nine.

A pilot study was conducted, consisting of informal interviews with retirees and staff at retirement villages. This served as the starting point for snowball sampling and the development of an interview guide. The interview guide focussed on what the retirees enjoyed most about being retired, the challenges of retirement, and what retirees could recommend to overcome these challenges. The interviews lasted approximately 90 minutes each.

Field notes were kept during the investigation. The notes consisted of observations during the pilot study and focus groups; participants' comments prior to or after focus groups; and tentative interpretations during data collection and the analysis procedures.

\section{Data analysis}

Initially, the data were divided into three broad categories, namely negative factors inhibiting self-actualisation, positive factors promoting self-actualisation and ways of overcoming challenges. Thereafter a bottomup strategy was adopted, as follows (Johnson \& Christenson, 2000:426-431):

- Segmenting. This involved dividing the data into 
meaningful analytical units. This was done by reading through the transcripts and identifying units of text that were important for the research. These units (words, sentences or several sentences) were bracketed to indicate where they began and ended.

- Coding. The identified units were given broad and abstract category names and coded with symbols. For example, missing work was indicated by MW and health problems by HP. All the category names and codes were put on a master list. The categories were further investigated for possible relationships between them. Thus, for instance, it became evident that missing work and health problems were sub-categories of the category called factors that inhibited self-actualisation.

- Facesheet codes were also given to single transcripts to enable comparison of groups. Thus groups one, two, three and four were coded G1, G2, G3 and G4 respectively.

- Checking for intercoder and intracoder reliability. The researchers checked each others' codes for consistency .

\section{FINDINGS AND DISCUSSION}

The findings revealed the following patterns:

\section{Satisfying aspects of retirement}

\section{Freedom from work-related difficulties}

A satisfying aspect of being free from work-related difficulties was the freedom from time constraints. Illustrative comments include: "I don't have to regimentally stick to time" and "If you wanted to go away, you could go away". Related to this was the freedom from work responsibilities: "My first relief was being relieved of responsibility - not to have that heavy sense of obligation and worry about people". For those participants who did not enjoy their work, retirement was seen as a relief. One stated: "My company was in a transitional period and I wasn't very happy with what was happening ... so in actual fact I was very glad to get out". This confirms the findings of Quick and Moen (1998:45) that retirement can offer an escape from problems at work.

\section{The freedom of choice regarding the use of free time}

Retirement for all participants meant an increase in free time. One participant stated: "For the first time I have time for myself. ... You're always being a wife, a mother, an organiser, every kind of managerial skill that comes to mind and now suddenly there is you - you've got time to go to a gym, you've got time to hike, you've got time to read". Many participants used this free time to serve the community, for example, serving their church, doing volunteer work or taking up activities that gave them a sense of purpose. One participant experienced satisfaction from beautifying public gardens, starting a hiking club and serving on the committee of a local retirement association. In accordance with the role theory and the activity theory, this illustrates how participants created new roles for themselves so that they could use time meaningfully and stay active and productive (Aiken, 1995:278).

\section{The opportunity to enrich social relation- ships}

For many participants retirement has meant the opportunity to invest time in social relationships. For example, participants discovered that retirement afforded them the opportunity to renew the intimacy and camaraderie of marriage relationships. One woman stated: "I think it is the bonding you have with your husband or wife. Perhaps you missed out on this - bringing up children and suddenly you find somebody who is absolutely wonderful and you didn't recognise all those marvelous qualities or give those qualities the due and respect that should have been there... suddenly you have honeymoon days again". Male/female roles started to blur as marriage partners shared chores. Moreover, many couples embarked on new ventures with their spouses, for example crafting items to sell, farming, employment at a guest lodge or travelling. The above-mentioned confirms that marital relationships change after retirement and that an increase in marital satisfaction is possible (Kulik, 1999:286-293).

Family relationships seemed to be highly valued by retirees. Grandchildren were regarded as a "blessing". One retiree declared: "Our family keeps us busy. I don't have a weekend free for myself, which is very nice actually".

Community involvement and peer relationships are regarded as especially valuable by those living in retirement homes and by those without family support. One 
participant commented: "We're very lucky at our retirement centre ... we're just one big, happy family! We're all buddies together".

To summarise: The retirees had to build new social relationships after retirement. Marriage partners, family (especially children and grandchildren), as well as fellow retirees were all important role players in providing social support, preventing social isolation and promoting self-actualisation.

\section{The challenges of retirement}

\section{Loss of the work role}

Many participants missed working. One stated: "I thoroughly enjoyed my job and it took me about a year or two to get used to retirement, because I enjoyed going to work so much". Some participants missed specific aspects of their work, for example, the children if he or she was a teacher, or the companionship of co-workers. Others found it difficult to adjust to a more relaxed lifestyle. A wife explained that her husband only seemed content when he was working on some project. He became irritated when encouraged to pursue leisure activities.

Retirement for many meant loss of authority and status: "When you retire ... the playing fields are level. The fact that you've been a doctor or a dentist or a minister-you're all just the same ... some people can't let go of that". One husband still expected his wife to fulfil tasks that had been performed for him, for example bringing tea, or getting someone on the phone to whom he wished to speak. This indicated lack of adjustment to loss of status, respect and authority, and inhibits self-actualisation. The problem of the loss of the work role also confirms previous findings (Aiken,1995:277; Le Roux, 1999:128).

\section{Time management}

Although some retirees considered the increased free time a benefit, others (especially males) found it daunting. Some became involved in church meetings, hobby meetings and crafts to keep busy: "I was very scared of being bored, so I joined a few organisations - but now I land up having a bit too much responsibility". When the activity theory of Maddox (Aiken, 1995:278; Knott, 1998:38) is considered, it seems as if the retirees responded in individual and sometimes different ways to the issue of how much activity each needed to be content.

\section{Location and housing}

Most participants found moving stressful. One participant related: "I think the most stressful thing in my life was when we actually decided to come down to George and I had to sell the house and get everything sorted out". This was aggravated by the fact that the couple had to make new friends: "It took about 18 months to be accepted by the community".

Many participants discovered that moving meant having to adjust to different living conditions. For many it meant smaller homes, smaller gardens, different facilities (for example, hospitals and shops) and climatic changes. These changes "... can be quite traumatic".

Participants mentioned that there was sometimes difficulty in gaining access to retirement homes. Places were often full or expensive: "It took twelve years for my name to get to the top" and "...people who bought there 15 years ago, now they can't afford it anymore" were some of the comments made. Conforming to the rules of retirement homes also proved a challenge. "I will resist tooth and nail any person trying to say we cannot have pets, because of the therapeutic importance of a pet", one said. In addition, it was a challenge to adjust to smaller living quarters and living in close proximity to others.

\section{Financial difficulties}

As noted in the literature review, adaptation (selfactualisation) is easier for those with sufficient income. However, many participants noted that financial difficulties were an integral part of their retirement experience. One couple, who had been retired for over 20 years, explained that although they believed that they had made adequate provision for their retirement, they are now finding it difficult to cope financially. "I think one of the main challenges is to keep up with the finance part [of retirement]". When early retirement is enforced, financial burdens are increased by the cost of the higher education of children. Some retirees become involved in "quick-rich schemes" or gambling and unethical financial advisors often exploit retirees: "There are a lot of these brokers who are all there for what they can get out of it". 


\section{Health problems}

Most participants were of the opinion that health is the most important determinant of the nature of one's retirement. "One's health has an enormous influence on what you can do in retirement. l'd put health above finances", one said. Another stated: "Once your health goes, your retirement becomes an absolute burden".

\section{Social relations}

In accordance with the findings of Wilkerson and Hichens (1989), some participants found that when a husband retires, a housewife often has considerable adaptations to make. One woman confessed that she found it frustrating when her husband needed an account of her whereabouts and when she had to rush home at lunchtime to prepare his meal. Moreover, if one spouse is very dependent on the other, this could put a strain on the marriage relationship: "... it's like having a young child who becomes cross with you for doing something they could have done themselves".

Although a few participants received financial assistance from their adult children, two male retirees experienced difficulty as a result of their family's financial dependence on them. They said: "When your children say: 'You know l'm broke, can you give me some money'... It just goes on and on".

Many South African retirees have children who live elsewhere, or even abroad. The response to this varied. As one retiree confirmed, "... about $80 \%$ had children who lived far away, many of them overseas or were scattered in different parts of the country". Another said: "I do miss my grandchildren, because I feel I'm missing out on something". The married participants living in retirement complexes seemed to adjust more easily to their children living far away. They pointed out the disadvantages of having one's family living close by: "Those people who have children close by ... they talk about the problems they have ... I say luckily ours are not close to us ... I don't want to know their problems".

Although most participants valued peer relationships and have been able to make new friends, married participants in retirement homes mentioned some difficulties in relating to certain peers. They stated: "You get a lot of people who focus on little things that you normally wouldn't worry about". Another complained: "One of the ladies phoned me at five o'clock and asked me to flatten the mole hills, because the cat was worried about it". In addition, some participants encountered irritating habits common to some people of their own age: "You get a few chaps that talk about their achievements the whole time ... that can drive you mad!" and "He doesn't want to listen to stories about your children, because he's trying to tell about his", or "You get the same story over and over again". Thus, although Carter and Cook (1995:69) reported that the social support of fellow retirees is important for self-actualisation, some social relations prove to be a burden, especially when it comes to fellow retirees who are not selfactualising individuals.

\section{Aging}

Maslow (1972) has identified autonomy as an important characteristic of self-actualisers. In this regard, independently living participants said that they feared loss of independence and saw it as a major problem related to aging: "My biggest fear is that I'll lose my independence". Associated with this, is the loss of mobility: "Mobility, walking or car driving, is very necessary for independence and getting to meetings or outings or places of interest". And: "My son made me sell my car - he said I was not getting enough exercise and boy, do I miss it now!'. Most participants mentioned their actual decline in physical and mental health, or their fear of such a decline, including memory loss: "We had an old man in our street. He was in his pajamas, walking to George".

The most traumatic experience for widowed participants was the loss of their spouse, which was described as "shattering" or "the worst experience of my life", and which lead to loneliness. Coping with the death of friends confront retirees with their own mortality and the meaning of life, as reported by previous authors (Atchley, 1988:110; Le Roux, 1999:129).

Aging can also make one feel out of touch in today's world. In this regard, reference was made to computers. This highlights the question to what extent the elderly should still actively try to be in touch with new developments, or should relinquish these activities to younger people.

\section{Psychological difficulties}

Feeling lonely was a difficulty mentioned by many single participants. Depression and/or suicide was alluded to 
in three of the four focus groups. However, it was not a problem experienced directly by the participants themselves, but rather by people whom they knew. "I know this chap who was a busy farmer ... he retired and started drinking and within six months he was dead! I think he felt useless and had no purpose in life", one recalled. A major cause of loneliness is feelings of rejection: "At our age nobody wants you any longer". Feeling lonely, depressed and suicidal are indicators of a lack of self-actualisation, as identified by Maslow (1970:150).

Another problem was fellow retirees' negativity. Some became "stuck in the past", in a desperate attempt to hold on to a time when they enjoyed recognition and status.

\section{Ways of overcoming challenges and experiencing fulfilment during retirement}

The findings revealed that the main factors enhancing self-actualisation during retirement involved handling certain key life areas successfully. The participants recommended the following strategies.

\section{General recommendations}

Most participants repeatedly mentioned the importance of acceptance: "You're starting a new chapter and you mustn't keep reading the old chapter ... I miss terribly a garden and trees, the sound of the sea ... that's past, you can't harp back the past!" Closely linked to acceptance is the willingness to make adjustments: "Your attitude is very important", and "You've really got to adapt your life". The attitudes, which were recommended, included maintaining a sense of humour, being positive and being open to new experiences.

The importance of involvement was also mentioned: "I think the main thing is just to be occupied and to keep an interest going". The importance of planning, not only prior to retirement, but also during retirement, was stressed. This involved a periodic re-evaluation of needs, the setting of appropriate goals, and plans of action to fulfil these goals.

The importance of faith in God was mentioned repeatedly. Many retirees spent time doing church activities, such as Bible study. Moreover, faith helped them face death, find meaning in life, and overcome challenges:
"If things go wrong and you've got no faith ... how do you hang on, and what helps you through if things get bad and difficult?"

\section{Effective coping with the loss of a work role}

Some retirees coped by phasing out their work role by gradually cutting down on work over a number of years. In accordance with the activity and continuity theory, others continued to engage in activities related to their previous work experience (being "semi-retired"). For example, a former nurse did voluntary nursing, and a medical doctor attended eye clinics at the local hospital and thereafter became involved with an AIDS hospice. Others managed by making complete lifestyle changes. For example, three couples were involved in farming on a smallholding. Whatever strategy was chosen, it seemed that what was most important was the willingness to let go of previous positions: "I think it's a very, very healthy thing to be what you are and not what you were". Thus, there is also some confirmation of the disengagement theory, as outlined by Cumming and Henry (Aiken, 1995:277). The participants stressed that retirees should embark on new challenges and activities.

\section{Effective time management}

Participants who recommended countless activities to keep busy confirmed the activity theory. These included do-it-yourself projects around home, community and church involvement, hobbies, and involvement in associations and clubs. "Take up something like bricklaying ... Make fences around your vegetable garden - l've just done a whole [flower] bed with trellises.... I enjoy watching rugby and cricket".

\section{Effective selection of location and hous- ing}

Most participants accepted that one's place of residence may change after retirement and stressed the importance of selecting a retirement-friendly and safe environment. The benefits of retirement villages or homes included being a member of a community and freedom from concerns about a garden or a pool. Such plans should be made timeously. On moving to a new location, an effort should be made to become involved with the community in some way. This indicates how important social relations can be for self-actualisation. 


\section{Effective handling of finances}

Most participants stressed the need for financial planning long before retirement and for scaling down financially after retirement. "Frugality is absolutely a way of life ... I now buy with discretion, I check prices, I look at flyers and I see where the best prices are". Sometimes retirees earned extra money through part-time work.

\section{Effective health management}

Participants stressed that retirees should take definite steps to prevent physical and mental decline: "Keep yourself fit! I go to a gym", and: "I have a lot of fruit ... do my own cooking and [housework] ... it keeps me busy and fit". Ways to obtain mental stimulation included joining book clubs, doing crossword puzzles, exploring the Internet, playing bridge or games, meeting new people (for example, doing hospital visitation) and maintaining a positive attitude. The need for regular medical check-ups was also emphasised. Participants who already had health problems noted the importance of taking active steps to improve these conditions. One man with a degenerative muscle disease declared: "I was told that by the age of 50 l'd be in a wheelchair ... I went to gyms and I trained ... determination ... kept me going and I'm now 66 and I am not in a wheelchair yet".

\section{Meaningful social involvement and support}

The married participants were more expressive than the single participants and the focus groups with married participants took longer than those with single participants. This suggests the effect on single people who lack a companion with whom to communicate. All the participants stressed the importance of meaningful social relationships.

Most participants recommended compromise in the marriage relationship. Each couple has had to find their own unique way of handling their particular relationship. Second marriages, marriages in which the one spouse is dependent on the other, and marriages where the wife has never worked outside the home present different challenges. In one example, a male participant who had been married for 57 years developed 10 rules, which have assisted him and his wife in their marriage since retirement. These included aspects such as "a sense of humour, give and take, tolerance and politeness".
Most couples discovered that the marriage roles in retirement were less clearly defined.

Many participants stressed the importance of maintaining meaningful relationships with one's children and grandchildren. These relationships should involve the giving and receiving of love and support. However, a few participants warned that one should not become too dependent on one's family. This once again highlights the importance of autonomy for self-actualisation. One daughter, although loving and supportive, told her mother that she should live her own life, "which I did ... and the bridge club was a big help". For those participants who had family that lived far away, electronic mail or telephone communication was a great advantage.

The importance of having meaningful relationships with friends was also emphasised, particularly by those who were widowed. Retirees living in retirement homes highlighted the support in these communities: "It's a big happy family ... we don't all think alike, but we are always there for each other". The consensus was that new friends should be made and old friendships, with their shared memories, should be maintained. Married participants living in retirement complexes stressed the importance of social skills: "We are very careful not to join the gossip groups", and: "You find a lot of people who keep repeating their stories".

Apart from the above, participants stressed the importance of community involvement. This included volunteer involvement with the church, gardening and hospital visitation: "We are all volunteers in the gardens ... and the church - all volunteers!"

\section{Autonomy}

As mentioned on several occasions, Maslow (1972) believed that autonomy is required for self-actualisation. Accordingly, all the participants emphasised the importance of maintaining independence, of doing things for themselves, and of living independently for as long as possible. "It is helpful not to leave your house and go into an old-age home ... rather just try and live in your own house", and "You've got to do your own cooking, clean your house" were some of the recommendations. Independence could be maintained through partial dependence on, or interdependence with other retirees: "If I fall in my house, all I do is talk on my cellphone", and: "My neighbour ... takes my dog for a 
walk twice a day". Being able to walk or drive oneself was considered significant for independence. Using delivery facilities also helped. However, it was also considered important to accept when the time came when one had to live dependently, or stop driving: "My mom went to the retirement centre when she was about 85 ... she didn't want to go ... my sister was already old herself ... how can she look after my mom and help her out of the bath?"

\section{Coping with loss and decline}

Coping with the loss of others is an inescapable aspect of aging. Most participants mentioned acceptance, while others mentioned re-marriage or holding on to memories as ways of coping: "My wife died of cancer and l've forgotten that more or less. I can only remember the happy days with her", and "If you're happily married the first time ... you want to get married again as soon as possible" were some of the comments that were made.

Coping with physical and mental decline and ultimately death is another aspect of aging which was mentioned. Ways of coping with the prospect of death included life review and an attitude of acceptance of the life one has lived, which is similar to ego-integrity (Erikson et al. 1986:54): "It is no use, especially at the end of your life, wishing you were somebody else". Participants mentioned that "living in the present" can help one to accept the inevitability of death, as well as to continue to live optimally until it occurs. Many participants mentioned that faith helped them face their own death: "I haven't got a fear of dying ... you have to have your belief in God".

\section{Remaining involved and in touch with con- temporary life}

The participants maintained that to age successfully, means "still being with-it" and in touch with one's environment: "The Germans have a wonderful saying: It doesn't matter how old you get, you've always time to learn". This gives some support to the activity theory and indicates that to actively learn new skills means to grow and hence to self-actualise.

\section{Maintaining psychological health}

The participants seemed to have maintained psychological health by achieving success in all of the areas mentioned above. Most participants repeatedly men- tioned the importance of strong faith, an overall positive attitude to life, the need to adjust constantly to changing circumstances, and the need to maintain meaningful relationships and activities. This fosters selfactualisation. Even late in life one can continue to grow. The therapeutic value of pet ownership was mentioned. All of the participants also noted the therapeutic value of the focus groups: "I think discussions like these would be helpful for people ... I've really enjoyed it and I do go ... with a little bit different attitude back than I came this morning".

\section{CONCLUSIONS}

The study was conducted with a select group of retirees living in a small area of South Africa. The findings may therefore not be applicable to retirees of other cultures and socio-economic groups, or retirees living in other places in South Africa, in institutions or in an extended family set-up. This is acknowledged as a limitation of the study. Nonetheless, the findings illustrate how each of the theories mentioned in the literature review (the activity, disengagement, role and continuity theories) was useful in understanding the factors related to selfactualisation during retirement. To illustrate: For selfactualisation, retirees need activity to prevent boredom and live meaningful lives. However, retirees also need to be able to disengage from their previous roles and responsibilities and to relinquish these to younger people. Retirees need some continuity in their lives and self-actualisation is enhanced if interests and hobbies are identified some time before retirement, in preparation for the event. New roles also have to be identified according to individual needs and preferences and these have to be adapted to. However, the precise applicability of each theory depends on the individual retiree and his or her circumstances.

For self-actualisation, retirees need healthy attitudes to the self and they should work at mental and spiritual growth. Retirees need as much autonomy as possible, but it should be tempered with an accurate perception of reality, considering the individual circumstances and abilities of each person.

Although the study illustrated how self-actualisation during retirement is an individual journey, programmes can be designed to support retirees on this journey. The programmes should preferably be presented to pro- 
spective retirees at churches or community centres, or by employers. Among other things, the programme content could include information on the retirement process and factors that promote self-actualisation during this time. Common changes and challenges and ways of achieving success could be covered. Some key areas are time management, housing, financial matters, physical and mental health, and social interaction. The responses to retirement which have been shown to generally foster adjustment and self-actualisation could be included. Citing the circumstantial factors which facilitate adjustment can make retirees aware of, and encourage them to appreciate satisfying aspects of retirement. Retirees have to be made aware of general modes of behaviour which enhance self-actualisation (for example, openness to new experiences). Retirees also have to be encouraged to find solutions to retirement problems by accepting challenges which cannot be changed, re-evaluating their own retirement situation and adjusting goals accordingly, and by initiating a plan of action and executing this plan. Thus, a waste of human potential may be prevented.

\section{BIBLIOGRAPHY}

AIKEN, LR 1995: Aging: An introduction to gerontology. Thousand Oaks: Sage.

ATCHLEY, RC 1988: Social forces and aging; fifth edition. Belmont, California: Wadsworth.

BALTES, PB \& BALTES, MM 1990: Confronting developmental tasks in the retirement transition. Gerontologist, 30(3):362-368.

CARTER, MAT \& COOK, K 1995: Adaptation to retirement: Role changes and psychological resources. The Career Development Quarterly, 44(1):67-82.

CHARLTON, K 1998: Health, health care and ageing in Africa: Challenges and opportunities. Southern African Journal of Gerontology, 7(2):1-3.

DYCHTWALD, K 1999: Age power. New York: Penguin Putnam. ERIKSON, EH; ERIKSON, JM \& KIVNICK, HQ 1986: Vital involvement in old age. New York: WW Norton.

FOUQUEREAU, E; FERNANDES, A \& MULLET, E 1999: The Retirement Satisfaction Inventory: Factor structure in a French sample. European Journal of Psychological Assessment, 15(1):4956.

FRIGENTI, R 2000: Making the most of retirement. Accountancy SA, May 2000:15-17.

GILLESPIE, CWI \& LOUW, J 1993: Life satisfaction in old age and activity theory: should the debate be re-opened? Southern African Journal of Gerontology, 2(1):25-30.
HARRIS, DK 1990: Sociology of aging; second edition. New York: Harper \& Row.

HESLOP, A; AGYARKO, R; ADJETEY-SORSEY, E \& MAPETLA, T 2000: The contribution of older people to society: evaluation of participatory research methodology employed in studies in Ghana and South Africa. Southern African Journal of Gerontology, $9(2): 6-12$.

HONG, LK \& DUFF, RW 1997: Relative importance of spouses, children, and friends in the life satisfaction of retirement community residents. Journal of Clinical Geropsychology, 3(4):275282.

JOHNSON, B \& CHRISTENSON, L 2000: Educational research: Qualitative and quantitative approaches. Boston: Allyn \& Bacon. KOWAL, PR; WOLFSON, LJ \& DOWD, JE 2000: Creating a minimum data set on ageing in sub-Saharan Africa. Southern African Journal of Gerontology, 9(2):18-23.

KERR, PP 2002: Guidelines for a psycho-educational programme to enhance self-actualisation of retired people. Pretoria: University of South Africa (M Ed Dissertation).

KNOTT, HD 1998: Die evaluering van ' $n$ psigo-opleidingsprogram vir die optimalisering van lewenskwaliteit na aftrede. Potchefstroom: Potchefstroomse Universiteit vir Christelike Hoër Onderwys (MA-verhandeling).

KULIK, L 1999: Continuity and discontinuity in marital life after retirement: Life orientations, gender role ideology, intimacy, and satisfaction. Families in Society, 80(3):286-294.

LE ROUX, K 1999: The realisation of meaning in old age. Educare, 28(1):121-135.

MASLOW, AH 1970: Motivation and personality; second edition. New York: Harper \& Rowe.

MASLOW, AH 1972: The further reaches of human nature. New York: Viking.

MEIN, G; HIGGS, P; FERRIE, J \& STANSFIEDL, SA 1998: Paradigms of retirement: The importance of health and ageing in The Whitehall II Study. Social Science \& Medicine, 47(4):535-545.

MOKONE, JM 1999: The role played by the family as a support system for the elderly and the challenges of caregiving. Social Work, 35(2):133-137.

NHONGO, TM 2000: Research for practice and development in Africa. Southern African Journal of Gerontology, 9(20):1-5. PHASWANA, MRN 1998: A study on the impact and effects of retirement on retirees in the Northern Province. Sovenga: University of the North (MA dissertation).

PRICE, CA 2000: Women and retirement: Relinquishing professional identity. Journal of Aging Studies, 14(1):81-101. POGGENPOEL, M 1998: Data analysis in qualitative research. (In: De Vos, AS ed. 1998: Research at grass roots: A primer for the caring professions. Pretoria: Van Schaik, pp 334-353.)

QUICK, HE \& MOEN, P 1998: Gender, employment, and retirement 
quality: A life course approach to the differential experiences of men and women. Journal of Occupational Health Psychology, 3(1):44-64.

SAGNER, A 1999: Reflections on the construction and study of elderliness. Southern African Journal of Gerontology, 8(2):16.

SMITH, SD 1997: The retirement transition and the later life family unit. Public Health Nursing, 14(4):207-2216.

VISSER, B; VAN WYK, R; SENEKAL, M \& UYS, R 1993: Clothing needs and related problems of female social pensioners in Stellenbosch. Southern African Journal of Gerontology, 2(2):17-22.

WILKERSON, JP \& HICHENS, P 1989: Marriage round the clock: 52 ways to stay happily married even though your husband's retired. London: Quiller. 